RESEARCH ARTICLE

\title{
Participatory Deliberative Democracy in Complex Mass Societies
}

\author{
Mark E. Warren
}

\begin{abstract}
What might participatory deliberative democracy look like in complex, mass societies? Cristina Lafont's Democracy Without Shortcuts (2019) challenges us to revisit this question by taking contemporary democratic theory to task for recommending a variety of shortcuts that would seem to reconcile democratic self-government with complex, mass societies, but do so by requiring 'blind deference' of citizens to decisions made by others. Here I make three general points. First, democracy is possible in mass, complex societies just because democratic societies and governments are full of shortcuts, through representation, political, epistemic and advocacy divisions of labour, differentiated institutions, multilevel governance, and trust relationships both among citizens and between citizens and governments. Few of these shortcuts require 'blind deference' of citizens. Second, because complex societies are highly differentiated in their structures, they also multiply opportunities for participation in ways that Lafont does not theorise owing to a statist focus on constitutional, rights-based politics. But, third, in arguing against shortcuts, Lafont underscores the importance of assessing the many kinds of principal-agent relationships in complex mass societies to ensure they advance rather than undermine the norms of participatory deliberative democracy.
\end{abstract}

Keywords: minipublics; participatory deliberative democracy; democratic theory; trust blind deference; democratic shortcuts

\begin{abstract}
Introduction
What might participatory deliberative democracy look like in complex, mass societies? Cristina Lafont's Democracy Without Shortcuts: A Participatory Conception of Deliberative Democracy (2019) challenges us to revisit this question with the provocative claim that we can and should conceive of a participatory deliberative democracy without shortcuts. A 'shortcut' is any political institution or set of practices that limits or damages the defining feature and rationale for political participation, self-government through the offering and receiving of public reasons for collective laws and policies. A 'participatory' deliberative democracy would be a polity in which each citizen participates in this essential feature of self-government. Lafont takes contemporary democratic theory to task for recommending a variety of shortcuts that would seem to reconcile democratic selfgovernment with complex, mass societies, but do so by requiring 'blind deference' of citizens to decisions made by others. If we believe in democratic self-government, she argues, we must conceive of 'democracy without shortcuts'.

Can we conceive of a democracy without shortcuts in complex mass societies? I shall make three general points. First, as has long been noted in democratic theory, democracy is possible in mass, complex societies just
\end{abstract}

University of British Columbia, CA

warrenme@mail.ubc.ca because democratic societies and governments are full of shortcuts, through representation, political, epistemic and advocacy divisions of labour, differentiated institutions, multi-level governance, and trust relationships both among citizens and between citizens and governments. Few of these shortcuts, however, require 'blind deference' of citizens. Second, because complex societies are highly differentiated in their structures, they also multiply opportunities for participation in ways that Lafont does not theorise owing to a statist focus on constitutional, rightsbased politics. But, third, in arguing against shortcuts, Lafont underscores how important it is to theorise and assess the large numbers of principal-agent relationships in complex mass societies to ensure they are compatible with the appropriately demanding norms of a participatory deliberative democracy.

In the first section, I develop and underscore the importance of Lafont's overall normative approach and framework: we should own our polities, and we should actualise ownership through political participation and mutual justification of the laws and policies. In the second section, I take a closer look at Lafont's understanding of why and what kinds of shortcuts are anti-democratic: they amount to 'blind deference' to the decisions made by others, undermining self-government. While her criticisms of many kinds of shortcuts are precise and land squarely, her criticisms of deliberative minipublics tend to miss their functions and purposes. In the third section, I 
argue that Lafont's state-centric view of democracy-she focuses primarily on participation in constitutional rights politics-unnecessarily constrains our views of spaces of politics, and thus opportunities for participation. If we want a robust conception of participation that is appropriate for today's complex, mass societies, we need to think about the spaces and places where participation is most important to self-government through something like the 'all-affected' principle: if someone is affected by a collectivity-local or global, associative, state, or marketthey should have the standing and capacities to influence the decisions of a collectivity. In the fourth section, I argue that no robust democracy in complex mass societies can do without shortcuts for reasons of size and complexity. Because in complex, mass societies people are embedded in multiple demoi, shortcuts are inevitable-even when the normatively important standard is participatory self-government. But because Lafont equates shortcuts with 'blind deference', we cannot ask a fundamentally important question: within complex, mass societies, what kinds of shortcuts underwrite and expand selfgovernment, and what kinds short-circuit? If we believe in participatory deliberative democracy, we should also be thinking about shortcuts that involve good citizen judgement, and about the ways that shortcuts can enable citizens to use their time, intelligence, and attentiveness to maximum effect.

\section{Norms of Democracy}

Lafont's book aims to return deliberative democratic theory to a participatory conception of democracy, one in which citizens participate in making their polities, sufficiently that they can experience ownership of them, and recognise themselves in laws and policies. Lafont's is a 'return' to a participatory conception of deliberative democracy in the sense that she is guided and inspired by Jürgen Habermas's originating formulations, which were radically democratic in inspiration, but also very much guided by early (neo-Kantian) critical theory ideals of autonomy: individuals should be able to reflect upon, justify, and articulate their interests and values. The normative approach Lafont takes to building democratic theory is the right one in my view: she begins with an intuitive ideal of democracy as self-government, and then builds institutional considerations around this idea. Her concept of 'participation' builds on this idea: people should participate in, and assent to, the laws, policies, and common projects through which collective selfgovernance is achieved. Following deliberative democratic theory, she places a heavy emphasis on mutual justification among citizens, and between citizens and governments, particularly those decisions that are binding.

Two consequences follow. First, the institutions of democratic should protect and empower spaces for deliberation, within public spheres, and within the institutions of government that make binding decisions, particularly legislatures and courts. Like Habermas (1996: chapters 3-4), Lafont places a special emphasis upon the constitutional rights and liberties that underwrite public space and empower participation, and thus provide the institutional architecture for mutual justifications. This emphasis leads Lafont to view constitutional issues, advocacy for rights, and processes of judicial review as the most important spaces of participatory deliberative democracy (Lafont 2019: chapter 8)-a topic to which I return below.

Second, Lafont rightly insists that we need to understand participation from the citizen's point of view. Her emphasis on a strong and even existential meaning of 'self-government' is one of the more important features of her approach-and gives normative depth to her critique of 'shortcuts'. Borrowing from Rawls, Lafont argues that participatory deliberative democracy should cultivate and realise "the two moral powers of citizens, i.e. their capacity for a sense of justice and for a conception of the good'that is, it should achieve, through cultivation of citizen capacities, both justice and a sense of identity linked to the good (20). Participation should generate a sense of ownership over both the laws and policies, particularly with respect to their relevant moral qualities; it should produce the effect of avoiding 'political alienation', by anchoring participation in its effects over both identity and justice:

With respect to the identitarian aspect, the importance of citizens being able to live in a world that conforms to their judgements partly has to do with their ability to develop a sense of fit and connection by seeing their values affirmed in the society they live in, their ideas recognised and reflected in their shared culture, and so on. It is important for citizens' identity and self-esteem to be able to shape the social world they live in so that they can find both meaning in what they do and value in their forms of life (20).

And citizens are not simply concerned with their status as political equals. They are also equally concerned with the reasonableness of the laws and policies that they must obey. No amount of equalisation of political power can compensate or substitute for citizens' fundamental interest in preserving their sense of justice-their interest in avoiding being forced into wronging themselves or others by having to blindly obey laws that, by their own lights, violate fundamental rights and freedoms (21-22).

Thus, a participatory conception of democracy must (1) identify all the relevant ways that citizens participate in shaping the political process in order to (2) articulate proposals for improving democratic institutions and practices, so that they (3) provide equal and effective opportunities of participation in shaping political decisions to all citizens (27).

\section{The Problem of Shortcuts}

It's now easy to see why 'shortcuts', particularly those that involve 'blind deference' to the judgements of others, are the problem for Lafont. Any delegation of participation and decisions to others-not just technocrats, but also procedures, minipublics, or anything else that would stand in for citizens' participation and judgements-will shortcircuit the very processes that underwrite the normative value of democracy. The only acceptable kind of shortcut, 
in Lafont's view, is elected representation. At least in principle, voters can know the positions and policies of the representative, and the representative can be selected and removed through election (Lafont 2019: 127-128). For citizens, what reconciles this kind of shortcut with democracy are two key factors. The first is that deference must be informed and there are good reasons to defer. The second is that those to whom we defer can be held accountable for the decisions they make. In such cases, citizens retain their democratic powers of judgement.

The kinds of shortcuts that don't pass the democratic test are those that involve 'blind deference'. 'A political system that requires citizens to blindly defer to political decisions made by others is quintessentially incompatible with the democratic ideal of self-government' (22-23). By 'blind', Lafont means that deference lacks any reasons or empowerments with respect to those making decisions and enforcing laws and policies. There are no democratic ways to generate political legitimacy outside of people being convinced that collective decisions are justified, even if they don't always get their way.

Lafont's normative framework and critical device of 'blind deference' cut powerfully against several strains of democratic theory, each of which propose shortcuts to decision-making. 'Deep pluralists' such as Jeremy Waldron, hold that political disagreement is intractable, and thus the democratic legitimacy of laws and policies cannot rest on agreement without, in effect, marginalising 'politics', which exist just because of disagreement (Lafont 2019: chapter 2). For this reason, in Waldron's view, democratic legitimacy must attach to procedures, particularly majority rule. This approach shortcuts the democratic norm that citizens persuade one another, while pushing the legitimacy problem into regress: if deep disagreement on laws and policies can't be justified in their substance, why would people be less inclined to disagree about the legitimacy of majority rule? Why should a minority 'blindly defer' to a majority, especially if they deeply disagree about the matter at hand?

Lafont criticises agonistic democrats for similar reasons (chapter 2.4). Agonists are critical of deliberative democracy because its emphasis on agreement and consensus fails to recognise that power differences may be normalised through deliberative processes among unequal participants. Lafont rightly notes that those who are disadvantaged in power relations often have the most to gain through persuasion. Moreover, agonistic political conflict-conflict between adversaries rather than enemies-usually presupposes a terrain of conflict structured by rights so that conflicts can be conducted in democratic ways. Rights, however, are political achievements that are only effective to the extent that they are widely recognised and accepted. Consensus on rights enables agonistic conflicts to occur on democratic terrain. Agonists 'shortcut' these essential, deliberatively achieved empowerments that enable conflict to be conducted democratically.

Lafont's case against 'elite epistocracy' (as in Brennan's Against Democracy 2016) is even more straightforward (chapter 3.1). Building on long-standing research that reveals the breadth and depth of citizen ignorance about the most basic features of law, policy, and even their own elected representatives, elite epistocrats propose handing over political decisions to those who are, in fact, experts-a strategy that appears increasingly appealing with the current rise of ignorant populisms. But, of course, this shortcut around citizen participation and justification assumes that expert classes of decision-makers would be well-intentioned; that they have deep knowledge of the values and circumstances of citizens; and that citizens would 'blindly defer' to their judgements. The theory is not just anti-democratic; it is also highly unrealistic.

Lafont turns some of her sharpest criticisms against what she calls 'democratic epistocracy' and 'lottocratic deliberative democracy'. Her target in the first category is Hélène Landemore (2013), who has developed a highly interesting and original justification for democratic inclusion and deliberative democracy on the basis of its epistemological benefits for public judgements (Lafont 2019: chapter 3.2). The 'shortcut' is that Landemore justifies democratic inclusion for epistemological reasons: a diversity of perspectives generates epistemically better public judgements, indicating, possibly, that democratic inclusions are only necessary to the extent that they add to epistemic diversity (92-93). This approach, Lafont argues, shortcuts the democratic ideal that laws and policies should be justified among citizens not because policies are epistemically better, but because people need to be persuaded by the policies to which they are subject. I find this argument strained at best, as Landemore's is a 'plus/and' argument, not an 'either/or' argument. Deliberative democracy can and should be justified from both perspectives.

More interesting, however, is Lafont's argument against 'lottocratic' conceptions of deliberative democracy-that is, the highly popular view among deliberative democrats that deliberative minipublics can represent broader publics, while providing for high-quality learning and deliberation among a select group of citizens willing to commit to the time and attention that good deliberation requires (Setälä \& Smith 2018). Lafont develops in detail a worry first articulated by Simone Chambers (2009): in focusing so much attention upon the minipublic device, deliberative democrats risk giving up on deliberation and participation by broader publics (Lafont 2019: chapter 4). Thus, if minipublics function within democratic systems as a 'micro-deliberative shortcut' (108) to informed and deliberative opinion that represents (counterfactually) what people would think if they were informed and had deliberated about their positions (e.g., Fishkin 2018), then they are, in effect, replacing mass justifications with the judgements of minipublics, thus trading off deliberation and participation. Because the normative point of deliberative democracy is self-government, this kind of shortcut amounts to a demand that people "blindly defer' to minipublics. But I do not find it convincing to claim, as Lafont does, that devices such as deliberative minipublics might back-track or damage democratic development. Most real-life deliberative minipublics serve to democratise non-democratic processes, such as 
bureaucratic decision-making. Nor is there any evidence to support the idea that minipublics crowd out public opinion formation. The little bit of research we have suggests that minipublics enhance rather than displace public opinion formation because they serve to focus public attention on an issue (Gastil \& Knobloch 2019).

But there are, in Lafont's view, properly democratic and participatory uses of minipublics. She is against stateempowered deliberative minipublics that would substitute their judgement for publics' judgements. She does favour uses of minipublics to provoke and focus broader public deliberations: 'Deliberative democrats should endorse the use of minipublics for shaping public opinion, not political decisions' (Lafont 2019: 136). It is worth noting, however, that the critique of deliberative democrats ends up being quite narrow in most cases, and not quite on target in others. From an empirical perspective there are very few examples of empowered deliberative minipublics. They are almost always advisory to broader publics (as with the British Columbia Citizens' Assembly on Electoral Reform, Oregon's Citizens Initiative Reviews, and the recent Irish Citizens' Assemblies on abortion and gay marriage) or advisory to bureaucracies (as with most policy-focused minipublics). There are a few instances in which deliberative minipublics have been empowered to devise a referendum question, as was the case with the British Columbia case (Warren \& Pearse 2008). While agenda-setting is an important kind of decisionmaking power, in these cases voters had the final say. There is broad interest among deliberative democrats in proposals for upper chambers selected through sortition within bicameral systems, which might inject both better representation and deliberative capacities into electoral bodies. In these cases, (legislative) minipublics would have real veto powers, but would also share powers with elected bodies (Dryzek \& Niemeyer 2008; Gastil \& Wright 2019; Leib 2004). In Wenling, China, an ongoing process that combines Deliberative Polling and Participatory Budgeting is empowered to, but the alternative isn't a participatory deliberative democracy, but rather status quo authoritarianism (Fishkin et al. 2010)! But mostly those who argue for deliberative minipublics do not make the case for direct empowerment. Rather, the arguments are usually for minipublics to supplement existing institutions. Lafont's (2019: chapter 6) argument ultimately lands here, as she appeals to systematic views of democratic systems, within which minipublics would help to provoke, guide, and deepen broader public discourse.

\section{The Scope of Participation in Complex Mass Societies}

I now turn to another issue-one that Lafont puts back on the agenda of deliberative democratic theory by insisting that we recover and rethink a participatory approach. As suggested above, Lafont's justification is strong, both normatively, and as an approach to building democratic legitimacy. At the end of the day, citizens should feel that they own their polities and politics and they should experience their polities as extensions of their agency. If they do, they are likely to view their polities as legitimate.
This said, participatory ideals need places to land in complex, mass societies. Here Lafont's approach remains underdeveloped in two ways that make it unnecessarily difficult to conceive of a participatory deliberative democracy. Because of our increasingly dense and extensive collective interdependencies, there are multiple new sites of potential political participation (Warren 2002). Yet for the same reason, most of the laws and policies that affect us will be made without much participation, and it is hard to see how it might be otherwise. Both trends can be at work at the same time, and we need to theorise both if we are to figure out what a participatory deliberative democracy might look like going forward. With respect to theorising the first set of possibilities, Lafont's approach is overly statist-focused primarily on constitutional matters-in such a way that she theoretically constrains the scope of participatory politics, thus under-theorising its possibilities. Second, her condemnation of 'shortcuts' is so general that she sweeps away the many kinds that might make a participatory deliberative democracy work in complex mass societies, a point to which I return in the next section.

With respect to questions of scope, Lafont is primarily concerned with unjustified state coercion, as well as opportunities for citizens to form, frame, and pressure for the most important laws within constitutional regimesthe rights and related constitutional fundamentals that provide the architecture of democratic citizenship (2019: chapters 7-8). Although centrally important, Lafont's framing tends to theorise away many of the problems and possibilities of participatory influence in complex, mass societies. If we want to know what, how, and where participatory deliberative democracy might land and thrive, we need to ask about where politics exists in today's interconnected worlds. That is, we should be thinking of 'democracy' as responding to sites of politics. State-based jurisdictions will remain key sites, and the constitutional architecture of citizenship establishes the protections, spaces, and standings that underwrite participation. But much of the action is above and outside of states, within global interconnections and regimes, within civil societies (local and global) and associations, networks that respond to markets and market structures, and so on (see, e.g., Dryzek 2010).

So, how do we begin to gain a theoretical handle on the scope and places of politics in complex mass societies? Lafont provides a key starting point with her strong normative emphasis on self-government. But her approach is truncated by the view of the boundaries of politics implicit in state-centric approaches: she uses what democratic theorists increasingly call the allsubjected interests' principle of democratic inclusion (or, alternatively, the boundaries of entitlements/claims for political influence) (Abizadeh 2012; see Fung 2013). Lafont's primary concern is important but limited: she argues that the core principle of deliberative democracy should be the public justification of coercive laws and policies. What's right about this idea is that no collectivity can do without binding laws. In a democracy, coercion is acceptable only if it's justified to those who are potentially or actually coerced. What follows, however, is a conception 
of the demos that is reactively constituted by the possibility of subjection to state coercion. But in a world in which issues flow across boundaries, and within which there are many kinds of collectivities, we need to conceive the potential domains of democracy with a more generic principle of inclusion: people should have entitlements to those collective matters that actually or potentially affect them-not just those that follow from actually or potentially coercive laws. Thus, for example, problems imposed on people by climate change aren't the result of coercive laws so much as they are externalities that reflect failures of collective action, and exist in a vacuum of laws and policies. Issues such as these bind us together not through laws or potentials for state coercion, but through shared 'affectedness'-through common problems and fates (Williams 2007). These sites of politics are potential spaces for democracy and participation.

An account of standing or entitlement that captures the full range of issues that impact self-government, and that should be the objects of self-government is going to require something more like the 'all affected principle' (Bohman 2007; Fung 2013). We're not there yet in theory or practice-indeed, the idea has been used rather casually and without close theoretical articulation by democratic theorists for several decades now (e.g., Habermas 1996: 105-111; Young 2000: chapters 1-2). But that is where democratic theory should be aiming: we should begin with the problem of the conditions and supports that are most important for self-government, ideally through a social justice lens that prioritises those relationshipsmodes of affectedness-that underwrite self-government.

A common objection to this approach is that, in an interconnected world, everything affects everything else, and so the principle would appear to constitute demoi that are impossible to sort into effective jurisdictions (Goodin 2007, 2016). Yet if we apply Lafont's strong principle of self-government, the all-affected principle looks much more tractable: we should care about participatory influence in those 'chains of affectedness' (to use a term from Bohman 2007) that impact most directly on selfgovernment-and these are to places where we should be most concerned about democratic participation. There are many mundane examples of just this kind of thinking in, for example, the practices of developed welfare states: every policy, and every need addressed by a policy, or every need that requires a policy, creates particular kinds of constituencies (or demoi): of parents and students for public schooling, neighbourhoods for urban planning, groups disproportionately affected by climate change, and so on. These kinds of actual or latent demoi amount to sites of participation that, for any individual or group with common needs, make self-government effective (Warren 2018a).

Importantly, many of the practical innovations in deliberative democracy address specific policy and 'governance' problems using just this logic, often within the administrative parts of governments (Warren 2014a). Likewise, many of the most important democratic innovations in recent decades actually bypass state-based policy altogether, using (for example) boycotts, branding, and focused buying to influence (say) overseas sweatshop labour, or the carbon footprints of products. Of course, each such area can, at the limit, involve threats to existing rights, or claims for new kinds of rights (Lafont 2019: chapter 8). Yet by theorising the spaces and scope for participation primarily in terms of the politics of rights, Lafont narrows the domain of participation in such a way that much of what counts as everyday politics falls aside. Participatory deliberative democracy should follow politics wherever it occurs, not just constitutionally relevant politics, crucial though they are.

Developing a theory of participatory deliberative democracy will require that we rethink sites of politics in complex, interdependent societies, particularly those that are constituted in ways that are important for selfgovernment. We can do so through a careful construction of the all-affected principle. In this view, equal rights provide protection and standing for participation, while a broader view of 'self-government' reveals opportunities for participation that will not be theoretically visible from a state-centric view of democracy. In this way, we can theorise the expanded domains for participation that exist in complex, mass societies, while connecting these domains back to the norm of self-government.

\section{Democratic Shortcuts}

The second piece of theory necessary to conceive of participatory deliberative democracy will be an account of the kinds of shortcuts we should want, and the places we might seek to locate them.

If we were to begin with problems of collective organisation in complex mass societies, shortcuts will appear in a different light than Lafont presents them-not just as matters of necessity, but also as ways of allocating citizens' participatory resources in ways that hold the most value for both identity and justice (MacKenzie \& Warren 2012). We will need to recognise that in complex mass democracies, no person can participate in but a few of those forces that affect their lives, however ideal they might be. This basic fact does not mean that the forces that affect our lives need be arbitrary, or that we have no control over them. What it does mean is that we need to think of 'self-government' as extended and realised through chains of principal-agent relationships. There is no 'democracy without shortcuts'.

In existing democracies, of course, we defer decisions that affect us to a wide variety of actors and institutions. We defer to representatives, political parties, and legislatures, enabling mass democracy. We defer to entities that hold a public trust, including most state bureaucracies, largely because bureaucracies organise professional expertise over vast domains of public services, purposes, and functions. They also carry out numerous tasks that require vast numbers of people to be on the job, freeing most others for other pursuits, including other kinds of work or specialisation, family, associational activities, and free time. We defer to judicial systems, including judges, lawyers, and clerks, as well to juries comprised of (more or less) randomly selected citizens. We defer to advocacy groups to represent causes in which we believe, 
and we defer to competent professionals-airline pilots, physicians, retirement fund managers, and so on. We should do so, usually, when we have reasons to believe that the interests of those to whom we defer align with our own. So what we need to decide, theoretically speaking, is this: what kinds of principal-agent relationships are democracy compatible and democracy enhancing? What we need is not 'democracy without shortcuts', but rather distinctions between good and bad shortcuts, given that it is scarcely possible to conceive of democracy in complex mass societies that isn't saturated by shortcuts.

With respect to this problem, Lafont's critical device of contrasting 'democracy' with 'blind deference', particularly as a way of distinguishing 'participatory deliberative democracy' from other theories of democracy, may actually push participatory deliberative democracy further from realisation. One problem is that Lafont's distinction isn't finely grained enough to distinguish non-democratic from democratic forms of deference. Deference can come in all kinds of undemocratic forms. Sometimes, deference can be 'blind'-but more often the problem is not that deference is blind, but just that it's not democratic. Deference can be knowingly traditional or paternalistic. Or it can be a rational response to undemocratic power relationships. People can knowingly defer to others who control their livelihoods, as when someone defers to their boss, not because they are 'blind', but because they might be fired if they don't.

Another problem with Lafont's critical device is that her target may not be 'blind deference' at all. Her real problem (and ours) is almost certainly with coerced obedience, in contexts in which those affected lack the power to respond. Lafont's formulations suggest as much: she is against shortcuts in which citizens are 'forced to blindly obey', or 'forced to blindly defer', or 'coerced into blind obedience' (2019: 102). These are contradictory formulas: if there is deference, then coercion should not be necessary. And once coercion comes into play, those subject to it might in fact obey, but obedience is unlikely to be either blind or deferential, but rather a rational response to a power relationship. So the real enemies of democracy are unjustified coercion and undemocratic forms of deference.

The distinction we need isn't between democracy and 'blind deference', but between warranted and unwarranted forms of deference, and between warranted deference and participation. With these distinctions, we can pose the question that we must in complex mass societies: what kinds of shortcuts make a participatory deliberative democracy possible, and what kinds are undemocratic or anti-democratic? I agree that many kinds of shortcuts are undemocratic, including many of those Lafont so nicely discusses. What we are missing is an account of those shortcuts that make democracy possible through divisions of political labour (see Bohman 1999; Elliott 2020).

Considered generically, shortcuts are compatible with democracy when they take the form of principal-agent relationships, and agents are empowered to hold their principals accountable (Warren 2014b). Individual level empowerments can take a number of forms, many of which are constitutionally enabled political and civil rights (voting, speech, association, petitioning, etc.), and some of which are enabled by welfare rights (education, income supports that enable exit from employers, etc.). Institution and system level conditions include choices within electoral systems and opportunities for exit in markets and civil society. These are standard points, of course, with which Lafont would agree.

As noted above, however, in any complex mass society individuals will be lodged within many, many principal-agent relationships, including not just elected representatives, but also the myriad government agencies that hold a public trust, associations that serve specific purposes, and advocacy groups that pressure on behalf of a cause or group. Because there are so many possibilities, it is important in a democracy that individuals be able to prioritise their attention, so they can focus on the issues that are most important to them, and where their monitoring might help to align their values or interests with those who decide and act on their behalf. For this kind of prioritising to be possible, it should also be possible for individuals to trust large numbers of agents, deferring to their judgements in some areas so they can attend to others. Trusted agents might include, for example, most public servants, advocacy groups that align with an individual's values or interests, and even elected representatives who have demonstrated the alignment of their values with those of constituents over time. In a well-functioning participatory deliberative democracy, warranted trust relationships should be ubiquitous. Indeed, in actually existing democracies, both social trust and trust in government tends to correlate with indicators of quality of democracy (Warren 2018b). Where there are high levels of trust, individuals can focus their political energies on those participatory venues they view as most important, and their monitoring activities on the agents that are less trustworthy-say, an elected representative or a political party that subject to many political crosspressures (Warren \& Gastil 2015).

Lafont (2019: 123-125) suggests that trust relationships are forms of 'blind deference' because they are not monitored, and can exist outside of deliberatively justified relationships. When individuals trust, they suspend judgement. But in a warranted trust relationship, judgements are suspended, not because individuals are 'blind', but because they have made a prior judgement that their interests or values align with those of the trusted agent. If trust is betrayed, individuals can return to monitoring, removing the agent, or exit the relationship. Warranted deference is always based on judgements that are far from blind. The payoff is that warranted trust can reduce the cognitive demands of citizenship to conceivable levels, while increasing the existential security essential to any kind of good human existence (Sztompka 1999). A participatory deliberative democracy should be the kind of system that supports warranted trust judgements, just because of the density of information and discursive relationships, and certainly not because they displace these relationships. Alternatively, a society populated by agents who must be monitored because of their untrustworthiness 
would be a society that is cognitively overwhelming and existentially insecure; one where collective organisation and actions would be difficult; and one where collective provision, at the heart of democratic self-government, would be all but impossible (Uslaner 2002).

In what ways might a participatory deliberative democracy support warranted trust relationships-a democratic form of deference? There are many pieces to this kind of puzzle, but many of us who have studied deliberative minipublics have been impressed by research that shows that citizens, when they know about them, tend to view them as trustworthy agents (Warren \& Gastil 2015). They can, as Lafont argues (2019: chapter 5.2), help to focus and stimulate public deliberation. But because they are designed as bodies that are descriptively representative of relevant publics, the interests and values of minipublic participants are often a good match with those of the public from which they are drawn. A participatory deliberative democracy that makes use of large numbers of deliberative minipublics would allow citizens to focus their participatory and monitoring activities on the issues they prioritise, while being able to trust that citizens like them are covering for issues they are not, perhaps, prioritising or even thinking about.

Throughout her book, Lafont (2019: 138) argues that we need to view participatory and deliberative spaces within a political system from a 'holistic, diachronic perspective' on participatory deliberative democracy. I couldn't agree more, as do an increasingly large number of deliberative democratic theorists (Bächtiger \& Parkinson 2019; Dean, Rinne, \& Geissel 2019; Mansbridge \& Parkinson 2012; Warren 2017). But if we're going to get there, we need to be thinking about expanding the scope of democracy to match emerging spaces of politics; about democracy-enhancing shortcuts that enable good divisions of participatory political labour; about new forms of representation that can supplement electoral representation; about ways of capturing the expertise of citizens, not as ways of replacing public opinion formation, but rather supplementing and democratising decision-making that is overly technocratic, bureaucratic, or simply too distant and detached from those who are affected.

\section{Competing Interests}

The author has no competing interests to declare.

\section{References}

Abizadeh, A. (2012). On the demos and its kin: Nationalism, democracy, and the boundary problem. The American Political Science Review, 106(4), 867-882. DOI: https://doi.org/10.1017/S0003055412000421

Bächtiger, A., \& Parkinson, J. (2019). Mapping and measuring deliberation: Toward a new deliberative quality. Oxford: Oxford University Press. DOI: https:// doi.org/10.1093/oso/9780199672196.001.0001

Bohman, J. (1999). Democracy as inquiry, inquiry as democratic: Pragmatism, social science, and the cognitive division of labor. American Journal of Political Science, 43(2), 590-607. DOI: https://doi.org/10. $2307 / 2991808$
Bohman, J. (2007). Democracy across borders: From dêmos to dêmoi. Cambridge, MA: MIT Press. DOI: https://doi.org/10.7551/mitpress/2327.001.0001

Brennan, J. (2016). Against democracy. Princeton, NJ: Princeton University Press.

Chambers, S. (2009). Rhetoric and the public sphere: Has deliberative democracy abandoned mass democracy? Political Theory, 37(3), 323-350. DOI: https://doi. org/10.1177/0090591709332336

Dean, R., Rinne, J., \& Geissel, B. (2019). Systematizing democratic systems approaches: Seven conceptual building blocks. Democratic Theory, 6(2), 41-57. DOI: https://doi.org/10.3167/dt.2019.060205

Dryzek, J. (2010). Foundations and frontiers of deliberative governance. Oxford: Oxford University Press. DOI: https://doi.org/10.1093/acprof:oso/9780199 562947.001.0001

Dryzek, J., \& Niemeyer, S. (2008). Discursive representation. American Political Science Review, 102(4), 481-493. DOI: https://doi.org/10.1017/S000305540 8080325

Elliott, K. (2020). Democracy's pin factory: Issue specialization, the cognitive division of labour, and epistemic performance. American Journal of Political Science, 64(2), 385-397. DOI: https://doi.org/10.1111/ ajps. 12486

Fishkin, J. (2018). Democracy when the people are thinking: Revitalizing our politics through public deliberation. Oxford: Oxford University Press. DOI: https://doi. org/10.1093/oso/9780198820291.001.0001

Fishkin, J., He, B., Luskin, R., \& Siu, A. (2010). Deliberative democracy in an unlikely place: Deliberative polling in China. British Journal of Political Science, 40(2), 435-448. DOI: https://doi.org/10.1017/S000 7123409990330

Fung, A. (2013). The principle of affected interests: An interpretation and defense. In R. M. Smith \& J. H. Nagel (Eds.), Representation: Elections and beyond (pp. 236268). Philadelphia, PA: University of Pennsylvania Press.

Gastil, J., \& Knobloch, K. (2019). Hope for democracy: How citizens can bring reason back into politics. Oxford: Oxford University Press. DOI: https://doi. org/10.1093/oso/9780190084523.001.0001

Gastil, J., \& Wright, E. O. (2019). Legislature by lot: Transformative designs for deliberative governance. London: Verso.

Goodin, R. (2007). Enfranchising all affected interests, and its alternatives. Philosophy and Public Affairs, 35(1), 40-68. DOI: https://doi.org/10.1111/j.10884963.2007.00098.x

Goodin, R. (2016). Enfranchising all subjected, worldwide. International Theory, 8(3), 365-389. DOI: https://doi.org/10.1017/S1752971916000105

Habermas, J. (1996). Between facts and norms: Contributions to a discourse theory of democracy. Translated by W. Rehg. Cambridge, MA: MIT Press. DOI: https://doi.org/10.7551/mitpress/1564.001.0001

Lafont, C. (2019). Democracy without shortcuts: A participatory conception of deliberative democracy. 
Oxford: Oxford University Press. DOI: https://doi. org/10.1093/oso/9780198848189.001.0001

Landemore, H. (2013). Democratic reason: Politics, collective intelligence, and the rule of the many. Princeton, NJ: Princeton University Press. DOI: https://doi. org/10.1515/9781400845538

Leib, E. (2004). Deliberative democracy in America: A proposal for a popular branch of government. University Park, PA: Pennsylvanian State University Press.

MacKenzie, M., \& Warren, M. (2012). Two trust-based uses of minipublics in democratic systems. In J. Mansbridge \& J. Parkinson (Eds.), Deliberative systems (pp. 95-124). Cambridge: Cambridge University Press. DOI: https://doi.org/10.1017/CB09781139 178914.006

Mansbridge, J., \& Parkinson, J. (Eds.) (2012). Deliberative systems. Cambridge: Cambridge University Press. DOI: https://doi.org/10.1017/CBO9781139178914

Setälä, M., \& Smith, G. (2018). Minipublics and deliberative democracy. In A. Bächtiger, J. Dryzek, J. Mansbridge \& M. E. Warren (Eds.), The Oxford handbook of deliberative democracy (pp. 300-314). Oxford: Oxford University Press.

Sztompka, P. (1999). Trust: A sociological theory. Cambridge: Cambridge University Press.

Uslaner, E. (2002). The moral foundations of trust. Cambridge: Cambridge University Press. DOI: https:// doi.org/10.2139/ssrn.824504

Warren, M. (2002). What can democratic participation mean today? Political Theory, 30(5), 677-701. DOI: https://doi.org/10.1177/0090591702030005003

Warren, M. (2014a). Governance-driven democratization. In S. Griggs, A. Norval \& H. Wagenaar (Eds.), Practices of freedom: Democracy, conflict and participation in decentred governance (pp. 38-59). Cambridge:
Cambridge University Press. DOI: https://doi.org/10. 1177/0090591702030005003

Warren, M. (2014b). Accountability and democracy. In R. Goodin (Ed.), The Oxford handbook of public accountability (pp. 39-54). Oxford: Oxford University Press. DOI: https://doi.org/10.1017/CBO9781107296 954.002

Warren, M. (2017). A problem-based approach to democratic theory. American Political Science Review, 111(1), 39-53. DOI: https://doi.org/10.1017/S00030 55416000605

Warren, M. (2018a). The all affected principle in democratic theory and practice. Democratic Inclusion in a Globalized World. A workshop hosted by the Harvard Kennedy School, June 2018.

Warren, M. (2018b). Trust and democracy. In E. Uslaner (Ed.), The Oxford handbook of social and political trust (pp. 75-94). Oxford: Oxford University Press. DOI: https://doi.org/10.1093/oxfordhb/9780190274801. 013.5

Warren, M., \& Gastil, J. (2015). Can deliberative minipublics address the cognitive challenges of democratic citizenship? Journal of Politics, 77(2), 562574. DOI: https://doi.org/10.1086/680078

Warren, M., \& Pearse, H. (2008). Designing deliberative democracy: The BC citizens' assembly. Cambridge: Cambridge University Press. DOI: https://doi.org/10. 1017/CBO9780511491177

Williams, M. (2007). Nonterritorial boundaries of citizenship. In S. Benhabib, I. Shapiro \& D. Petranovich (Eds.), Identities, affiliations, and allegiances (pp. 226256). New York: Cambridge University Press. DOI: https://doi.org/10.1017/CBO9780511808487.011

Young, I. (2000). Inclusion and democracy. New York: Oxford University Press. How to cite this article: Warren, M. E. (2020). Participatory Deliberative Democracy in Complex Mass Societies. Journal of
Deliberative Democracy, 16(2), pp. 81-88. DOl: https://doi.org/10.16997/jdd.395

Submitted: 28 February 2020 Accepted: 16 June 2020 Published: 14 October 2020

Copyright: ( $) 2020$ The Author(s). This is an open-access article distributed under the terms of the Creative Commons Attribution 4.0 International License (CC-BY 4.0), which permits unrestricted use, distribution, and reproduction in any medium, provided the original author and source are credited. See http://creativecommons.org/licenses/by/4.0/.

Wournal of Deliberative Democracy is a peer-reviewed open access journal published by University of Westminster Press.
OPEN ACCESS $\precsim$ 